Єщенко Марина Георгіївна

асистент кафедри економіки і менеджменту

Донбаська національна академія будівництва і архітектури, м. Краматорськ, Україна

ORCID ID 0000-0001-7467-7899

marinsv@ukr.net

\title{
ВИКОРИСТАННЯ ІНФОРМАЦЙНО-КОМУНІКАЦІЙНИХ ТЕХНОЛОГІЙ ЯК ЗАСОБУ ФОРМУВАННЯ ФАХОВОЇ КОМПЕТЕНТНОСТІ МАЙБУТНІХ МЕНЕДЖЕРІВ І ЕКОНОМІСТІВ У ПРОЦЕСІ НАВЧАННЯ ПРАВОЗНАВСТВА
}

\begin{abstract}
Анотація. У статті розглянуто проблему формування фахової компетентності студентів вищих навчальних закладів у викладанні курсу правознавства. Шляхом вивчення й аналізу науково-методичної літератури визначено поняття компетентність, фахова компетентність. Для формування фахової компетентності автор пропонує задачі, для розв'язання яких необхідно використовувати інформаційно-комунікаційні технології. Зазначено, що запропоновані засоби надають додаткові можливості для формування фахової компетентності, сприяють вдосконаленню інформаційної грамотності студентів вищих навчальних закладів i реалізації їнніх правових можливостей. Актуальність статті обумовлена необхідністю формування фахової компетентності студентів вищих навчальних закладів за допомогою використання інформаційно-комунікаційних технологій у викладанні курсу правознавства. Було проведено експеримент на базі Донбаської національної академії будівництва і архітектури.
\end{abstract}

Ключові слова: інформаційно-комунікаційні технології; майбутні фахівці; фахова компетентність студентів; хмарні технології.

\section{1. ВСТУП}

Гуманізація i демократизація українського суспільства, швидкий розвиток інформаційного простору, педагогічної науки зумовили суттєві зміни освітньої галузі, зокрема формування компетентностей студентів ВНЗ.

Постановка проблеми. Розвиток суспільства, заснованого на знаннях і нових суспільних відносинах, має базуватися на використанні наукових та інноваційних технологій, що підвищують якість життя людини. Побудова інформаційного суспільства в Україні регулюється Законом України «Про Національну програму інформатизації», Указом Президента України «Національна стратегія розвитку освіти в Україні на період до 2021 року». У зазначених нормативно-правових актах підкреслюється, що саме рівень інформатизації, уміння використовувати переваги інформаційно-комунікаційних технологій стають одними 3 важливих чинників розвитку країни. Водночас, у складних умовах трансформації суспільства, зростає значення освіти, що грунтується на принципах життєтворчості, метою якої є допомога у визначенні шляхів соціалізації індивіда і його правових знань [1].

Оптимальне і цільове використання переваг сучасних технологій для досягнення інноваційного розвитку освіти і виконання ії основних функцій згідно з Національною стратегією розвитку освіти в Україні на період до 2021 року, має бути спрямовано на те, щоб сформувати соціально і фізично творчу особистість, представника покоління інформаційної епохи, громадянина України; який вільно володіє засобами інформаційно-комунікаційних технологій у будь-якій ситуації [2]. 
Інтерес до проблем вищої освіти спостерігається в усьому сучасному прогресивному світі й пов'язаний, передусім, зі швидкими технологічними, соціальноекономічними, правовими змінами.

Перспективи розвитку вищої освіти вимагають визначення заходів, що формують фахові компетентності студентів вишу. Відтак постає необхідність удосконалення технології проведення занять 3 правознавства, а саме: методів і засобів навчання для формування фахової компетентності студентів ВНЗ засобами інформаційнокомунікаційних технологій.

Тому проблема організації навчання на курсах правознавства 3 використанням інформаційно-комунікаційних технологій, які сприяють формуванню предметних компетентностей студентів ВНЗ у галузі права, стає необхідною складовою правознавчої освіти [3].

Зважаючи на праці вчених щодо проблеми формування фахової компетентності студентів вищих навчальних закладів, залишаються недостатньо дослідженими переваги використання інформаційно-комунікаційних технологій як засобу підвищення фахової компетентності студентів ВНЗ.

Аналіз останніх досліджень і публікацій. В Україні, як і в інших країнах Європи i світу, відбувається віднаходження прийнятної для національної освіти компетентнісної моделі. Вагомі напрацювання у цій царині зроблено науковцями Національної академії педагогічних наук України Н. М. Бібік, О.В.Овчарук, О. I. Пометун, О. Я. Савченко, О. І. Локшиною. Як зазначає О. I. Локшина у дослідженні «Компетентнісний підхід у сучасній освіті: світовий досвід та українські перспективи» (2004) покладено початок дискусії навколо питання запровадження компетентнісного підходу в українську освіту [4, с. 51-60].

Проблеми набуття компетентностей і створення ефективних механізмів їх запровадження відображено в роботах О. В. Овчарук, запровадження компетентнісного підходу в освіті розглянуто в роботах Н. М. Бібік, В. Кальней, В. І. Лугового та О. І. Пометун, С. Шишова, питання реалізації компетентнісної ідеї в освіті зарубіжжя відображено в працях О. І. Локшиної, формування фахової компетенції розглянуто в працях Г. О. Безпала, Л. Б. Волошко, С. О. Скворцова, С. О. Цимбалюк [5]. Проблема впровадження технічних засобів навчання у навчально-виховний процес закладів освіти широко висвітлювалася в багатьох вітчизняних посібниках із професійної педагогіки, в окремих навчально-методичних виданнях, педагогічних енциклопедіях. Це саме праці С. Я. Батишева, Ю. Ф. Зіньковського, М. Ю. Кадемії, Н. Г. Ничкало, О. М. Новікова, В. В. Олійника, В. О. Скакуна, О. М. Царенко [6].

Певні аспекти використання інформаційно-комунікаційних технологій для організації навчання студентів ВНЗ і систему організації самостійної роботи студентів за допомогою хмарних сервісів відображено у роботах Г. А. Алексанян, використання інформаційно-комунікаційних технологій у викладанні правознавства розкрито в роботах С. І. Нетьосова, історію розвитку інформаційно-комунікаційних технологій розглянуто в роботах О.С. Воронкіна [7], створення освітніх ресурсів у середовищі moodle на основі хмарної технології у своїх дослідженнях розглядали науковці I. С. Войтович та В. П. Сергієнко [8].

Різні аспекти правової компетентності вивчалися А. Бочевар [9], Г. Кашкарьовим, Я. Кічук [10], Д. Клочковою, І. Романовою [11], Т. Ремех [12] та ін. Специфіку формування інформаційно-комунікативної компетентності майбутніх фахівців було відзеркалено у працях Л. Дідух, Н. Клещенкової, Т. Смирнової та ін.

Розглядаючи перспективи використання інформаційно-комунікаційних технологій у навчанні, науковець О.С. Воронкін у своїх дослідженнях звертав увагу на такі чинники, як: досягнення балансу між можливостями інформатики і дидактики; 
формування системи стандартів; досягнення інформаційної грамотності викладачів і студентів; орієнтація на відкритість, доступність, неперервність і масовість у використанні інформаційно-комунікаційних технологій. Кінцевою метою більшості педагогічних інновацій $є$ сприяння переходу від передавання студентам знань до формування компетентностей. Успіх у розв'язанні цього важливого завдання у більшості залежить від заходів і шляхів використання інформаційно-комунікаційних технологій, можливостей існуючого програмного забезпечення. Отже. актуальності набуває питання формування фахової компетенції майбутнього фахівця за допомогою використання інформаційно-комунікаційних технологій [13].

На думку дослідника О.С. Воронкіна, вищі навчальні заклади з перших курсів мають вчити студентів способам і прийомам «комп'ютерного мислення». Цей термін уперше використаний професором Дж. Вінг у 2006 р. Науковець вважає, що концепція комп'ютерного мислення має спиратися на універсальні, фундаментальні здібності та навички для всіх, у зв'язку з чим затребуваними стають педагогічні кадри, здатні реалізовувати можливості інформаційно-комунікаційних технологій у своїй професійній діяльності й готові до постійного вдосконалення свого професійного рівня [13].

Як справедливо зазначає Т. Ремех, правова освіта покликана сформувати у молодій людині такі якості: знання ролі права в суспільстві, векторів правового регулювання; навички застосування права в конкретних ситуаціях; комплексні характеристики вчинків як законних чи незаконних; ставлення до права як високої соціальної цінності; ставлення до правозастосовчої практики як до забезпечення дії закону; внутрішню готовність до дотримання правових приписів і конкретних вимог правомірної поведінки; готовність сприяти правомірній поведінці інших осіб [12], що уособлює правову компетентність.

У наукових дослідженнях визначено, що інформаційно-комунікаційні технології це система сучасних інформаційних методів, прийомів праці і їх організації на основі комп'ютерно-технічних засобів, спрямованих на збирання, зберігання, опрацювання, накопичення, передавання, розповсюдження, представлення й використання інформації, що розширює можливості людини в суспільній діяльності [3].

Автори сучасних досліджень зазначають, що хмарні технології передбачають використання програмного забезпечення як сервісу (SaaS - Software as a Service) i хмарні сервіси - це сервіси, призначені для того, щоб робити доступними користувачеві прикладне програмне забезпечення, простір для зберігання даних та обчислювальні потужності через Internet [14].

Розбудова України, становлення громадянського суспільства, розвиток демократії однією зі складових має високий рівень правової культури громадян, а фундаментом правової освіти $є$ правознавчі курси у закладах вищої школи.

Поняття «компетентність» введено у науковий обіг більш ніж чверть століття. Компетентний - який має достатні знання в якій-небудь галузі; який з чим-небудь добре обізнаний; тямущий. Компетентність - поінформованість, обізнаність, авторитетність [14].

Відповідно до Державного стандарту, компетентність складається із знань, умінь, досвіду, цінностей і ставлення, що можуть цілісно реалізовуватися на практиці [15].

Науковець О. В. Овчарук [16] зазначала, що Міжнародна комісія Ради Європи розглядає поняття компетентності як загальні, або ключові, уміння, базові вміння, фундаментальні шляхи навчання, ключові кваліфікації, кроснавчальні вміння або навички, ключові уявлення, опори, або опорні знання. Компетентності, на думку експертів РЄ, передбачають: 
- спроможність особистості сприймати і відповідати на індивідуальні й соціальні потреби;

- комплекс ставлень, цінностей, знань і навичок.

Таке визначення поняття компетентностей певним чином збігається 3 положеннями, що висловлюють українські педагоги, однак представники європейських педагогічних кіл насамперед виходять з особистісних і соціальних потреб, задоволенню яких мають сприяти компетентності. Міжнародна комісія Ради Європи розглядає поняття компетентності як загальні, або ключові, уміння, базові вміння, фундаментальні шляхи навчання, ключові кваліфікації, кроснавчальні вміння або навички, ключові уявлення, опори, або опорні знання [16, с. 19].

Метою статті $\epsilon$ охарактеризувати використання засобів інформаційнокомунікаційних технологій, які сприяють формуванню фахової компетентності студентів у викладанні курсу правознавства; виявити рівні сформованості фахової компетентності студентів на підставі результатів проведеного експерименту.

\section{2. МЕТОДИКА ДОСЛІДЖЕННЯ}

Для розв'язання поставлених завдань використано методи: теоретичний - для вивчення й аналізу науково-методичної літератури, навчальних програм, посібників, узагальнення інформації для визначення теоретико-методологічних основ дослідження; емпіричний - проведення експериментального дослідження.

\section{3. РЕЗУЛЬТАТИ ДОСЛІДЖЕННЯ}

Під час швидкого розвитку інформаційних технологій i їх використання в повсякденному житті, виникає необхідність внесення змін у процес виховання i навчання молоді. Сучасний абітурієнт, студент, як правило, має у своєму розпорядженні і використанні, окрім сучасного стаціонарного комп'ютера, ще й смартфон, ноутбук, нетбук, i-pad або планшет, які необхідно використовувати під час навчального процесу ВНЗ.

Оскільки йдеться про процес навчання і розвиток особистості, що відбувається в системі освіти, то одним із результатів освіти буде набуття людиною набору фахових компетентностей, що $є$ необхідним для професійної діяльності майбутнього фахівця.

Науковець О. В. Овчарук стверджує, що компетентність [16]:

- сприяє досягненню успіхів у житті;

- сприяє розвитку якості суспільних інститутів;

- відповідає багатоманітним сферам життя.

Згідно з визначенням Міжнародного департаменту стандартів для навчання, досягнення та освіти (International Board of Standards for Training, Performance and Instruction (IBSTPI) поняття компетентності визначається як спроможність кваліфіковано здійснювати діяльність, виконувати завдання або роботу. Наразі поняття компетентності містить набір знань, навичок та відношень, що дають змогу особистості ефективно здійснювати діяльність або виконувати певні функції, що підлягають досягненню певних стандартів у галузі професії або виду діяльності. Для того щоб полегшити процес оцінювання компетентностей, Департамент пропонує виділити 3 цього поняття такі індикатори, як набуті знання, уміння, навички та навчальні досягнення [16, с. 20].

Поняття «компетентність» також докладно вивчає вчений О. I. Пометун, яка вважає, що компетентністю людини можна називати спеціально структуровані 
(організовані) набори знань, умінь, навичок і ставлень, яких набувають у процесі навчання, і які дають змогу людині визначити, тобто ідентифікувати й розв'язувати, незалежно від контексту (ситуації), проблеми, притаманні певній сфері діяльності. Сформовані компетентності людина використовує за потреби, у різних соціальних та інших контекстах залежно від умов, і потреб щодо здійснення різних видів діяльності. Отже, компетентність - це результативно-діяльнісна характеристика освіти. Рівень компетентності є рівнем діяльності, необхідним і достатнім для мінімальної успішності в досягненні результату [17, с. 5].

Щодо переліку компетентностей, на думку науковця О. І. Пометун, відповідних освітнім традиціям і соціокультурному контексту сучасного українського суспільства, то очевидно, що найприйнятнішим для нас $є$ принцип їх відбору відповідно до сфер його життя, у яких нині особистість реалізовує себе і провадить свою діяльність. Нині триває обговорення переліку таких компетентностей і їх структури - переліку напрямів їх набуття студентами, формування в них здатності до провадження такого виду діяльності. Науковець вважає, що такий перелік буде базовим, мінімально необхідним 3 погляду досягнення успішної самоактуалізації особистості в названій сфері суспільного життя. Комплекс цих напрямів і зможе забезпечити певний рівень оволодіння компетентністю [18].

Дослідниця Н. М. Бібік розуміє під компетентністю - стосовно структури змісту освіти, який побудовано в сучасних стандартах за галузевим принципом, і в програмах - за предметним, - виводить метарівень, універсальний, що в інтегрованому вигляді представляє освітні результати, які досягаються не лише засобами змісту освіти, але й соціальної взаємодії; як у міжособистісному, так і в інституційному культурному контексті [18, с. 46].

На думку Н. М. Бібік аналіз контексту вживання поняття «компетенції» дозволяє розуміти його як соціально закріплений освітній результат. Тобто компетенції можуть бути виведені як реальні вимоги до засвоєння студентів сукупності знань, способів діяльності, досвіду ставлень 3 певної галузі знань, якостей особистості, яка діє в соціумі. Знаходимо спробу «компетентність», «компетенції» передати через усталені поняття: «комплекс умінь», «умілість», «готовність до...», «здатність до ...». Цей рівень компетентностей може характеризувати, на думку науковця Н. М. Бібік, предметні вимоги до засвоєння багатокомпонентного змісту освіти [18, с. 47].

В. В. Моштук стверджує, що похідним компонентом усіх видів компетентності $\epsilon$ фахова - інтегративна характеристика особистості, яка виступає показником освіченості (наявності професійної освіти), та:

а) проявляється у готовності і здатності до успішного здійснення професійної діяльності;

б) є переліком умов до фахівця у конкретній сфері;

в) визначає фахово важливі знання i вміння, особистісні й мотиваційні компоненти діяльності, усвідомлення іiі соціальної значущості і відповідальне ставлення до справи [19].

У результаті наукових досліджень С. О. Скворцова і С. О. Цимбалюк довели, що фахова компетентність визначає систему взаємовідносин набутих знань, умінь i навичок і здатності ефективно використовувати їх у реальній практичній діяльності. Автори підкреслюють, що фахова компетентність характеризується володінням людиною відповідною компетенцією, що включає його особистісне відношення до неї і предмету діяльності [5].

Л. Б. Волошко стверджує, що фахова компетентність віддзеркалює сутність спеціальності, яку опановує студент, тому може бути схарактеризована як концептуальна основа підготовки фахівця. Фахова компетентність відображає рівень 
сформованості професійних знань, умінь і навичок, його професійну ерудицію, що дозволяють успішно вирішувати три класи задач професійної діяльності: стереотипні, діагностичні та евристичні, що передбачені нормативно-правовими документами вищої школи [5].

Науковець Н. М. Бібік вважає, що компетентнісний підхід забезпечує перехід від процесу до результату освіти 3 погляду того, що $є$ актуальним і затребуваним у суспільстві [18, с. 45-50].

На нашу думку, науковець В. І. Луговий найбільше наблизився до розуміння сутності компетентнісного підходу, обгрунтувавши його методологічне розуміння у межах професійної підготовки фахівців у вищій школі. Дослідник поділяє компетентності на загальні й часткові. Загальна компетентність - це «...інтегральна характеристика особи, яка розкладається на диференціальні компетентності. Тобто загальна компетентність складається з окремих часткових компетентностей» [20].

Структура правової компетентності має свої особливості. Розуміючи правову компетентність як інваріантну суб'єктивну характеристику сучасної молоді, Я. Кічук вважає, що вона «вибудовується» на базі використання відповідних знань, умінь, досвіду, наявних іiї цінностей і життєвої позиції, а також інтегрує ставлення особистості [10] до правової дійсності; є важливою інтегративною особистісною якістю, підгрунтя якої - знання особистості та іiі досвід поведінки у правовій сфері життєдіяльності, а вияв - спроможність орієнтуватися в ситуаціях, пов'язаних із правовими відносинами [21]. I. Романова визначає правову компетентність як комплексну характеристику соціальної дії, у якій в єдності виявляються знання, навички, цінності, особистості установки і свобода поведінки [11].

Комбінування перелічених вище елементів дало змогу науковцям на загальному рівні виокремити компоненти компетентності: мотиваційний, когнітивний, рефлексивний, діяльнісний [18, с. 19], [9].

Саме здатність (уміння) особи діяти на основі здобутих знань В. Кальней та С. Шишов розуміють як іiі компетентність. Такій підхід дозволяє виокремити у структурі правової компетенції практично-поведінковий компонент, що включає вміння й навички застосовувати правові знання у різних ситуаціях. Також у цілісній структурі правової компетентності зазначаємо ціннісно-мотиваційний компонент, яким охоплюється: особистісне ставлення студента до права і держави; система цінностей i мотивація правової поведінки та реалізації права.

Когнітивний компонент включає спеціальні знання 3 правознавства, засвоєння яких студентами $\epsilon$ передумовою формування у них правової компетентності. Ще одна важлива складова когнітивного компоненту - це процедура отримання знань, необхідні вміння й навички роботи 3 джерелами правової інформації: підручником, словниками, довідниками, нормативно-правовими актами 3 метою отримання, накопичення, використання інформації, потрібної для розв'язання завдань у навчальній та позанавчальній діяльності; охоплює вміння самостійно здобувати правові знання, вільно, конструктивно й творчо використовувати їх, що передбачає вміння проводити певні логічні інтелектуальні операції, використовуючи ІКТ.

За результатами діяльності робочої групи 3 питань запровадження компетентнісного підходу, створеної в рамках проекту ПРООН «Освітня політика та освіта «рівний - рівному», запропоновано такий перелік ключових компетентностей:

- уміння вчитись (навчальна);

- громадянська;

- загальнокультурна;

- компетентність 3 інформаційних і комунікаційних технологій;

- соціальна; 
- підприємницька;

- здоров'язберігаюча.

Компетентності 3 інформаційно-комунікаційних технологій передбачають здатності:

- застосовувати сучасні інформаційні технології в навчанні і повсякденному житті,

- раціональне використання комп'ютера й комп'ютерних засобів у розв'язуванні задач, пов'язаних з опрацюванням інформації, іiі пошуком, систематизацією, зберіганням, поданням та передаванням;

- будувати інформаційні моделі й досліджувати їх за допомогою засобів інформаційно-комунікаційних технологій;

- давати оцінку процесові й досягнутим результатам технологічної діяльності $[18$, c. 88$]$.

На думку О. В. Овчарук, інтерактивне використання засобів передбачає розуміння загалу засобів, що дають можливість особистості взаємодіяти з навколишнім світом:

- здатність інтерактивно застосовувати мову, символіку та тексти означає ефективне використання мов і символів у різноманітних формах і ситуаціях для досягнення цілей, розвиткові знань i власних можливостей. Це дає можливість розуміти світ і брати участь у діалогах, а також ефективно взаємодіяти з оточенням;

- здатність використовувати знання й інформаційну грамотність означає ефективне використання інформації і знань, дає можливість особистості їх сприймати й застосовувати, використовувати їх як базис для формування власних можливих варіантів дії, позицій, прийняття рішень та активних дій;

- здатність застосовувати (нові) інтерактивні технології передбачає не тільки технічні здібності, ІКТ-уміння, а й обізнаність у застосуванні нових форм взаємодії з використанням технології. Ця компетентність надає можливість особистості адаптувати власну поведінку до змін в повсякденному житті [16, с. 24].

У формуванні правової компетентності студентів, ми вважаємо використання IКТ дуже важливим засобом у цьому тому, що саме цей засіб сприяє формуванню інтегративної якості особистості, що дозволить адаптуватися до довколишнього інформаційно-комунікаційного простору, виробляти власний стиль інфокомунікацій та нарощувати обсяги інформації і знань в умовах сучасних соціальнокультурних трансформацій.

Отже, спираючись на дослідження науковців 3 метою формування правової компетентності студентів вищих навчальних закладів, ми пропонуємо використовувати такі засоби інформаційно-комунікаційних технологій:

- за допомогою соціальних мереж, електронної пошти та інших сучасних технологій викладачі 3 різних країн можуть обмінюватися своїм досвідом роботи. А студенти вишу, у свою чергу, можуть допомагати один одному у вивченні нового матеріалу і пошуку потрібної інформації з певних тем, використовуючи систему національних інформаційних ресурсів. Одним із таких ресурсів у галузі юридичних наук $€$ Інтернет-ресурс «Правова наука», що створений і підтримується Науково-дослідним інститутом інформатики і права НАПрН України спільно з Управлінням планування та координації правових досліджень Апарату Президії НАПрН України. Ресурс «Правова наука» створено для задоволення потреб широкого кола фахівців, експертів і вчених у галузі права й містить узагальнену інформацію щодо сучасного стану наукових досліджень у цій сфері. Інтернет-ресурс «Правова наука» містить відомості 
щодо організації Національної академії правових наук України та її науководослідних установ та висвітлює основні нормативно-правові акти у сфері наукової і науково-технічної діяльності [22];

- використовувати освітні й навчальні електронні матеріали, електронні підручники, он-лайн книги й енциклопедії, які можна безкоштовно або за мінімальну оплату прочитати он-лайн у глобальній мережі Internet;

- он-лайнові щоденники студентів, які дають корисні інструменти молоді, та онлайн журнали викладачів;

- доцільно, ставити перед студентами ВНЗ й логічні завдання, які включають слова: «поясніть», «доведіть». Але пояснення й аргументованість відповідей студента вишу буде залежати від рівня його підготовки до такого виду питань, знань та вмінь використовувати в процесі навчання інформаційні технології й інформацію, отриману за допомогою інформаційно-комунікаційних технологій;

- уміння користуватися і застосовувати у професійній діяльності викладача та навчальній діяльності студентів ВНЗ різноманітні сучасні засоби - це лише половинна справи. Адже для мобільної, динамічної взаємодії потрібний засіб взаємозв'язку між тими, хто навчає, й тими, хто навчається. Нині для такої взаємодії успішно використовують хмарні технології. Використання хмарних технологій надає можливість одночасно працювати студентам і викладачам над одним проектом - виконувати завдання, проходити тестові завдання або розв'язувати задачі. Це допомагає розвинути вміння працювати в команді, уміння відстоювати свої ідеї, застосовувати «мозковий штурм» і ділитися своїми знаннями. Зручність також полягає в тому, що значна частина хмарних сервісів мають власні мобільні додатки для зручної і динамічної роботи з ними на таких пристроях як планшети і смартфони, використовуючи мобільну операційну систему iOS, Android та інші, що створює можливість мати постійний зв'язок з усіма особистими даними в будь-якому місці і будь-який зручний час [23], [24].

Під час практичних занять для розв'язання задач і проходження тестових завдань студенти вишу можуть використовувати систему національних інформаційних ресурсів.

Прикладом завдань для студентів можуть бути завдання у вигляді тестів закритої форми (вибір з множини, вибір «так»-«ні»). Цей формат тестових завдань дає змогу оцінити навчальні досягнення студентів вишу на різних рівнях: розуміння, знання і застосування знань.

\section{Завдання 1.}

Бухгалтер О. В. Василенко була прийнята на роботу у фірму «АБС» із строком випробування 2 місяці. Через два тижні вона захворіла і була відсутня на роботі 1,5 місяці. Після одужання О.В. Василенко вийшла на роботу, та їй сказали, що керівництвом фірми вона звільнена з роботи у зв'язку з незадовільним результатом випробування.

1. Чи правильно поступило керівництво фірми?
a) так;
б) нi.

2. Які строки випробування встановлені трудовим законодавством?
а) не може перевищувати трьох місяців;
б) не може перевищувати шести місяців за погодженням 3 відповідним виборним органом первинної профспілкової організації;


в) не може перевищувати одного року;

г) не може перевищувати двох місяців;

д) не може перевищувати одного місяця.

3. До строку випробування дні, коли працівник фактично не працював, незалежно від причини, повинні зараховуватися?

a) так;

б) нi.

Отже, застосування інформаційно-комунікаційних технологій на етапі вивчення нового матеріалу відкриває нові можливості для оволодіння правовими знаннями, уміннями і навичками, формування предметних компетентностей з правознавства [3].

Використання кейс-методу - ситуаційної методики, яка повинна підтримуватися достатньою кількістю наочних матеріалів 3 боку викладачів (статей 3 періодичних видань, он-лайн та відео-підтримкою). Такі заняття також вимагають використання інформаційних технологій та інформації.

Прикладом завдань для студентів можуть бути задачі в такому вигляді:

\section{Завдання 2.}

До відділу кадрів підприємства «ФОКС» звернулися із заявами про прийом на роботу:

a) А. І. Семенюк - економістом (демобілізований, до призиву в армію закінчив економічний коледж);

б) О. Л. Мудрик - учнем токаря (закінчив 11 клас, вік 17 років);

в) Д. Б. Бондаренко - експедитором, трудовий стаж 12 років.

1. Поясніть, які гарантії є при прийомі на роботу.

2. Вкажіть строки трудового договору.

3. Поясніть порядок укладення трудового договору.

4. Для кого з вищеперерахованих працівників можна встановити випробувальний строк? Поясніть відповідь.

5. Поясніть порядок випробування при прийомі на роботу і строки випробування.

Використання нестандартних занять - у формі рольової гри. Такі практичні заняття теж вимагають використання інформаційно-комунікаційних технологій. Проектуючи й моделюючи ті чи інші ролі, студенти отримують навички й уміння відповідної поведінки, яка наближає їх до реальної практики. Значну допомогу надають інформаційні ресурси, наприклад: Інтернет-ресурс «Правова наука»;

- студенти вишу можуть отримувати знання через створення й опрацювання навчального матеріалу. За допомогою сучасних технологій кожен студент може зробити презентацію, працювати з текстом, робити цифрові фотографії, малюнки, знімати відео, слухати веб-радіо або переглядати відеоканал, створювати 3D моделювання тощо;

- використання інноваційних методик дозволяє активізувати студентську аудиторію, оскільки не тільки формує, а ще й підвищує вміння знаходити взаєморозуміння, спільну мову під час роботи в міні-групах - перед студентами однієї групи ставиться загальне завдання;

- студенти ВНЗ також можуть створити сайт групи: вони вчаться мислити, створювати і спілкуватися;

- використовувати у навчанні мережні пошукові системи, наприклад: Google Scholar, яка дозволяє студентам виконувати великий пошук наукової літератури з різних дисциплін та з різних джерел; 
- використовувати у навчанні відеоконференції, наприклад: комунікаційні технології Facebook. Нині можна, наприклад, через Facebook влаштовувати зустрічі студентів 3 науковими працівниками. Також можна встановити зв'язок 3 видатними науковцями, спортсменами i будь-якими іншими цікавими людьми і після виступу можна буде ставити питання запрошеним гостям;

- використання в навчанні інтерактивних дошок і проекторів, які дають більше можливостей i зручностей для викладачів. Завдяки яким можна дивитися пізнавальні передачі, виступи, що надає можливість краще засвоювати нові знання студентами;

- завдяки використанню у навчанні відеоматеріалів і лекцій, які зберігаються на сайтах вишів, а також пересилаються студентам за допомогою Internet.

Найбільшим серед числа працівників освіти попитом користуються сервіси хмарних технологій таких корпорацій: Microsoft (пакет Microsoft Office 365), Google (служба Google Apps for Education) та IBM (IBM Collaboration Solutions). Вони дозволяють організовувати швидке впровадження і застосування хмарних технологій у навчальному процесі [23].

Логіка нашого дослідження вимагала виявлення стану сформованності фахової (правової) компетентності майбутніх фахівців. Для цього було проведено експеримент, який проводився на базі Донбаської національної академії будівництва і архітектури (надалі - ДонНАБА). В експерименті взяли участь 100 респондентів ДонНАБА, із них до експериментальної групи (ЕГ) і до контрольної групи (КГ) увійшли по 50 студентів.

Відповідно з визначенням і структурою фахової (правової) компетентності нами було визначено такі ㄲï критерії: мотиваційно-вольовий, гносеологічний, операціональний, оцінний.

Показниками мотиваційно-вольового критерію вважаємо інтерес і позитивне ставлення до застосування IКТ, цілеспрямованість i впевненість в успішному застосуванні IКТ - для діагностики цього критерію було застосовано адаптовану методику за М. Снайдером.

До показників гносеологічного критерію відносимо наявність знань щодо сучасних IКТ на рівні користувача і наявність знань щодо застосування IКТ в процесі комунікації - для діагностики було використано адаптовану методику Л. Бережнової.

Показниками операціонального критерію визначаємо такі: вміння використання IКТ 3 метою підвищення продуктивності спілкування; уміння прогнозувати шляхи підвищення ефективності своєї фахової діяльності 3 використання IКT - для діагностики було застосовано адаптовано методику Д. Барбуто.

До показників оцінного критерію виокремлюємо вміння застосовувати сучасні ІКТ для розв'язання завдань професійної діяльності, уміння використовувати IКТ з метою підвищення продуктивності спілкування - діагностика реалізовувалась за допомогою використання адаптованої методики С. Будассі.

Ступінь прояву кожного 3 показників, узятих у сукупності, визначає рівень сформованості фахової (правової) компетентності майбутніх фахівців засобами ІКТ. Нами було визначено чотири рівні сформованості фахової (правової) компетентності: високий, достатній, середній та низький.

Результати щодо рівнів сформованості критеріїв фахової (правової) компетентності майбутніх фахівців у викладанні курсу «Правознавство» в експериментальній групі подано в табл. 1. 
Таблиия 1

Рівні сформованості критеріїв фахової (правової) компетентності майбутніх фахівців у викладанні курсу «Правознавство» в експериментальній групі

\begin{tabular}{|c|c|c|c|c|c|c|c|c|c|c|c|c|}
\hline \multirow{2}{*}{$\begin{array}{l}\text { Критерії, } \\
\text { показники } \\
\text { (рівні, характер } \\
\text { виявлення) } \\
\text { сформованості } \\
\text { фахової } \\
\text { (правової } \\
\text { компетентності }\end{array}$} & \multicolumn{4}{|c|}{$\begin{array}{c}\text { ЕГ (до експерименту) } \\
\text { (50 студ.) }\end{array}$} & \multicolumn{4}{|c|}{$\begin{array}{c}\text { ЕГ (після експерименту) } \\
\text { (50 студ.) }\end{array}$} & \multicolumn{4}{|c|}{$\begin{array}{c}\text { Результати } \\
\text { експериментальної роботи } \\
\text { (приріст у \%) }\end{array}$} \\
\hline & 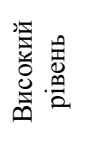 & 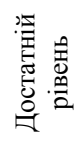 & 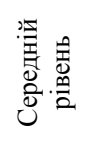 & 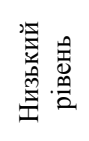 & 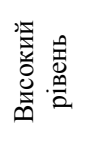 & 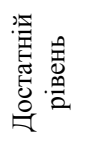 & 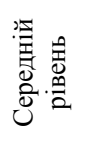 & 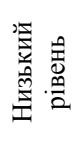 & 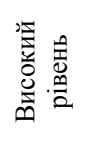 & 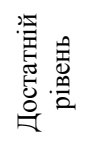 & 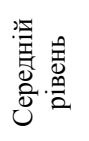 & 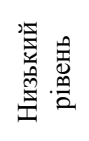 \\
\hline 1 & 2 & 3 & 4 & 5 & 6 & 7 & 8 & 9 & 10 & 11 & 12 & 13 \\
\hline $\begin{array}{l}\text { 1.Мотиваційно- } \\
\text { вольовий }\end{array}$ & $10 \%$ & $\begin{array}{l}14 \\
\%\end{array}$ & $28 \%$ & $48 \%$ & $20 \%$ & $30 \%$ & $16 \%$ & $34 \%$ & $\begin{array}{c}+10 \\
\%\end{array}$ & $\begin{array}{c}+16 \\
\%\end{array}$ & $-\overline{12 \%}$ & - \\
\hline 2.Гносеологічний & $8 \%$ & $\begin{array}{l}12 \\
\%\end{array}$ & $36 \%$ & $44 \%$ & $16 \%$ & $28 \%$ & $24 \%$ & $32 \%$ & $+8 \%$ & $\begin{array}{c}+16 \\
\%\end{array}$ & $\begin{array}{c}- \\
10 \% \\
\end{array}$ & $\begin{array}{c}- \\
12 \% \\
\end{array}$ \\
\hline $\begin{array}{l}\text { 3.Операціональ- } \\
\text { ний }\end{array}$ & $12 \%$ & $\begin{array}{l}14 \\
\%\end{array}$ & $38 \%$ & $36 \%$ & $26 \%$ & $24 \%$ & $30 \%$ & $20 \%$ & $\begin{array}{c}+14 \\
\%\end{array}$ & $\begin{array}{c}+10 \\
\%\end{array}$ & $-8 \%$ & $16 \%$ \\
\hline 4.Оцінний & $10 \%$ & $\begin{array}{l}26 \\
\%\end{array}$ & $24 \%$ & $40 \%$ & $26 \%$ & $30 \%$ & $20 \%$ & $24 \%$ & $\begin{array}{c}+16 \\
\%\end{array}$ & $+4 \%$ & $-4 \%$ & $\begin{array}{c}- \\
16 \% \\
\end{array}$ \\
\hline
\end{tabular}

Результати щодо рівнів сформованості критеріїв фахової (правової) компетентності майбутніх фахівців у викладанні курсу «Правознавство» в контрольній групі подано в табл. 2.

Таблиия 2

Рівні сформованості критеріїв фахової (правової) компетентності майбутніх фахівців у викладанні курсу «Правознавство» в контрольній групі

\begin{tabular}{|c|c|c|c|c|c|c|c|c|c|c|c|c|}
\hline \multirow{2}{*}{$\begin{array}{l}\text { Критерії, } \\
\text { показники } \\
\text { (рівні, характер } \\
\text { виявлення) } \\
\text { сформованості } \\
\text { фахової } \\
\text { (правової } \\
\text { компетентності }\end{array}$} & \multicolumn{4}{|c|}{$\begin{array}{c}\text { КГ (на початок } \\
\text { вивчення курсу } \\
\text { «равознавство») } \\
(50 \text { студ.) }\end{array}$} & \multicolumn{4}{|c|}{$\begin{array}{c}\text { КГ (наприкінці вивчення } \\
\text { курсу «Правознавство») } \\
\text { (50 студ.) }\end{array}$} & \multicolumn{4}{|c|}{$\begin{array}{c}\text { Результати } \\
\text { (приріст у \%) }\end{array}$} \\
\hline & 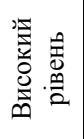 & 瞄 & 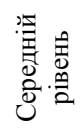 & 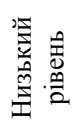 & 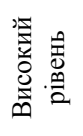 & 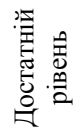 & 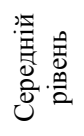 & 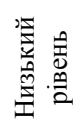 & 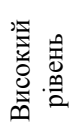 & 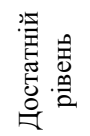 & 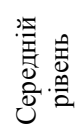 & 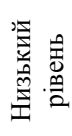 \\
\hline 1 & 2 & 3 & 4 & 5 & 6 & 7 & 8 & 9 & 10 & 11 & 12 & 13 \\
\hline $\begin{array}{l}\text { 1.Мотиваційно- } \\
\text { вольовий }\end{array}$ & $8 \%$ & $\begin{array}{l}12 \\
\% \\
\end{array}$ & $\begin{array}{l}34 \\
\% \\
\end{array}$ & $46 \%$ & $10 \%$ & $14 \%$ & $36 \%$ & $40 \%$ & $+2 \%$ & $+2 \%$ & $+2 \%$ & $-6 \%$ \\
\hline 2.Гносеологічний & $6 \%$ & $\begin{array}{l}14 \\
\%\end{array}$ & $\begin{array}{l}38 \\
\%\end{array}$ & $42 \%$ & $12 \%$ & $16 \%$ & $36 \%$ & $36 \%$ & $+6 \%$ & $+2 \%$ & $-2 \%$ & $-6 \%$ \\
\hline $\begin{array}{l}\text { 3.Операціональ- } \\
\text { ний }\end{array}$ & $\begin{array}{l}10 \\
\%\end{array}$ & $\begin{array}{l}16 \\
\%\end{array}$ & $\begin{array}{l}40 \\
\%\end{array}$ & $34 \%$ & $14 \%$ & $22 \%$ & $32 \%$ & $32 \%$ & $+4 \%$ & $+6 \%$ & $-8 \%$ & $-2 \%$ \\
\hline 4.Оцінний & $\begin{array}{l}10 \\
\% \\
\end{array}$ & $\begin{array}{l}26 \\
\% \\
\end{array}$ & $\begin{array}{l}38 \\
\% \\
\end{array}$ & $26 \%$ & $18 \%$ & $32 \%$ & $26 \%$ & $24 \%$ & $+6 \%$ & $+2 \%$ & $12 \%$ & $-2 \%$ \\
\hline
\end{tabular}

Отже, рівні сформованості фахової (правової) компетентності майбутніх фахівців (узагальнені дані) подано в табл. 3 і виявлено такими: високий рівень сформованості проявили 11 студентів (22\%) ЕГ та 7 студентів (14\%) КГ; достатній рівень - 14 студентів (28\%) ЕГ та 10 студентів (20\%) КГ; середній рівень - 11 студентів 
(22\%) ЕГ та 16 студентів (32\%) КГ; низький рівень - 14 студентів (28\%) ЕГ та 17 студентів (34\%) КГ.

Таблиия 3

Рівні сформованості фахової (правової) компетентності майбутніх фахівців (узагальнені дані)

\begin{tabular}{|c|c|c|c|c|}
\hline \multirow[b]{2}{*}{$\begin{array}{c}\text { Рівні } \\
\text { сформованості }\end{array}$} & \multicolumn{2}{|c|}{$\begin{array}{c}\mathrm{E} \\
\text { (50 студ.) }\end{array}$} & \multicolumn{2}{|c|}{$\begin{array}{c}\text { K } \\
\text { (50 студ.) }\end{array}$} \\
\hline & $\begin{array}{c}\text { констатувальний } \\
\text { зріз }\end{array}$ & контрольний зріз & $\begin{array}{c}\text { констатувальний } \\
\text { зріз }\end{array}$ & контрольний зріз \\
\hline 1 & 2 & 3 & 4 & 5 \\
\hline Високий & $\begin{array}{l}10 \% \\
(5 \text { ст. })\end{array}$ & $\begin{array}{c}22 \% \\
(11 \text { ст. })\end{array}$ & $\begin{array}{c}8 \% \\
(4 \text { ст. })\end{array}$ & $\begin{array}{l}14 \% \\
(7 \text { ст.) }\end{array}$ \\
\hline Достатній & $\begin{array}{l}16 \% \\
(8 \text { ст. })\end{array}$ & $\begin{array}{c}28 \% \\
(14 \text { ст. })\end{array}$ & $\begin{array}{c}18 \% \\
(9 \text { ст. })\end{array}$ & $\begin{array}{l}20,0 \% \\
(10 \text { ст.) }\end{array}$ \\
\hline Середній & $\begin{array}{c}32 \% \\
(16 \text { ст.) }\end{array}$ & $\begin{array}{c}22 \% \\
(11 \text { ст.) }\end{array}$ & $\begin{array}{c}38 \% \\
(19 \text { ст. })\end{array}$ & $\begin{array}{c}32 \% \\
(16 \text { ст.) }\end{array}$ \\
\hline Низький & $\begin{array}{c}42 \% \\
(21 \mathrm{cт} .)\end{array}$ & $\begin{array}{c}28 \% \\
(14 \text { ст.) }\end{array}$ & $\begin{array}{c}36 \% \\
(18 \text { ст. })\end{array}$ & $\begin{array}{c}34 \% \\
(17 \text { ст.) }\end{array}$ \\
\hline
\end{tabular}

Аналіз результатів експерименту підтверджує доцільність подальших досліджень щодо формування фахової (правової) компетентності майбутніх фахівців.

\section{4. ВИСНОВКИ ТА ПЕРСПЕКТИВИ ПОДАЛЬШИХ ДОСЛІДЖЕНЬ}

Сучасна європейська освіта орієнтована на використання компетентнісного підходу. Для впровадження такого в Україні треба чітко розуміти сутність понять «компетентність», «фахова компетентність».

Одним зі шляхів оновлення змісту освіти й узгодження його із сучасними потребами, інтеграцією до європейського і світового освітніх просторів є орієнтація навчальних програм 3 курсу правознавства на набуття фахових компетентностей студентів ВНЗ і на створення ефективних механізмів їх запровадження.

Правова освіта передбачає опрацювання великого обсягу правової інформації, що часто змінюється і не може зводитися лише до вивчення законодавства, до простої комбінації юридичних навичок відомостей, а має забезпечувати розвиток у студентів здатності керуватися відповідними знання в сучасному суспільному і повсякденному житті, уміння, діяти відповідно до вимог права, закону, вирішувати реальні завдання у сфері відносин, урегульованих правом, а також поєднання правових знань із внутрішньою позицією особистості.

Сучасні дослідження не можуть дати одностайного чіткого визначення терміну «фахова компетентність». На нашу думку - фахова компетентність, це не тільки знання, уміння та навички, вона може формуватися у процесі навчання й готовності студентів до нового виду діяльності, а також бути мотивацією до розв'язання задач. Отже, фахова компетентність є однією з головних характеристик майбутнього фахівця в сучасних суспільно-економічних умовах.

Формування фахової компетентності студентів вищих навчальних закладів 3 використанням інформаційно-комунікаційних технологій у викладанні курсу правознавства передбачає здатність студента орієнтуватись в інформаційному просторі, володіти й оперувати інформацією відповідно до потреб ринку праці. Вона пов'язана 3 якостями технічно і технологічно освіченої особистості, підготовленої до життя й активної трудової діяльності в умовах сучасного високотехнологічного інформаційного суспільства, що охоплюють основні компоненти інформаційної культури студентів, 
базовані на раціональному співіснуванні 3 техносферою, відповідно до їхнього професійного самовизначення з урахуванням індивідуальних можливостей.

Інформаційно-комунікаційні технології надають безліч потужних можливостей студентам здійснювати навчання он-лайн, займатися самоосвітою у зручний час та у комфортних умовах, вільно обмінюватися корисними і важливими матеріалами, не зважаючи на географічне місце розташування, отримувати повноцінні консультації в режимі реального часу та в стислі терміни і все це завдяки розміщенню необхідних матеріалів, даних і відомостей на віддалених серверах і без прив'язки до стаціонарного комп'ютера.

Одним з найефективніших засобів, що сприяють формуванню правової і фахової компетентностей, $€$ засоби IКТ, використання яких тісно пов'язане 3 головним напрямом розвитку суспільства початку XXI століття - інформатизацією як сукупністю взаємопов'язаних організаційних, правових, політичних, соціально-економічних, науково-технічних, виробничих процесів, що спрямовані на створення умов для задоволення інформаційних потреб громадян і суспільства на основі створення, розвитку і використання інформаційних систем, мереж, ресурсів та інформаційних технологій, які побудовані на основі застосування сучасної обчислювальної та комунікаційної техніки.

Отже, ми дійшли висновку, що для формування фахової (правової) компетентності студентів найбільш доцільним $є$ використання таких засобів IКТ: електронні таблиці; засоби контролю і самоконтролю навчальних досягнень; засоби створення мультимедійних презентацій; пошукові системи загального призначення; системи підтримки навчання; текстові редактори; хмаро орієнтовані засоби підтримки спільної навчально-дослідницької діяльності; адаптивні автоматизовані навчальні системи з курсу «Правознавство»; електронні періодичні системи; кейс-метод; науковопопулярні та юридичні інформаційні ресурси Internet; програмно-методичні комплекси навчального призначення з курсу «Правознавство»; електронні практикуми.

Отже, використання інформаційно-комунікаційних технологій у навчальному процесі залишається перспективним і актуальним напрямом, який стрімко й динамічно продовжує розвиватися.

\section{СПИСОК ВИКОРИСТАНИХ ДЖЕРЕЛ}

[1] В. Примаков, “Розвиток післядипломної освіти вчителів початкових класів в Україні (19482012pp.)”, дис. д-ра. пед. наук., Тернопільськ. нац. пед. ун-т ім. В. Гнатюка, Тернопіль, 2016.

[2] Президент України (2013, Черв. 25) Указ №344/2013, Про Національну стратегію розвитку освіти в Украӥні на період до 2021 року. [Електронний ресурс]. Доступно: http://zakon4.rada.gov.ua/laws/show/344/2013/page.

[3] С. Нетьосов, "Використання інформаційно-комунікаційних технологій на уроках правознавства", Інформаційні технологї $i$ засоби навчання, №3 (23), 2011. [Електронний ресурс]. Доступно: http://journal.iitta.gov.ua/index.php/itlt/article/view/489/417. Дата звернення: Травень. 23, 2017.

[4] О. Локшина, “Компетентнісний підхід в освіті: теоретичні засади і практика реалізації”, матеріали методол. семінару, Ч.1, Ін-т обдарованої дитини НАПН України, Київ, 2014.

[5] Г. Безпала, “Компоненти фахової компетентності майбутніх учителів”, Проблеми інженернопедагогічної освіти, №44, с. 14-18, 2014.

[6] Н. Смоляна, "Використання ТЗН у навчально-виробничому процесі професійної школи в Україні (1960-1991 pр. ХХ століття)”, Інформаційні технологї $і$ засоби навчання, №2 (22), с. 1 - 14, 2011. [Електронний ресурс]. Доступно: http://journal.iitta.gov.ua/index.php/itlt/article/view/349/391. Дата звернення: Травень. 23, 2017.

[7] О. Воронкін, “Розвиток комп’ютерних технологій підтримки навчання студентів вищих навчальних закладів України (друга половина 50-х - початок 90-х років XX ст.)", Інформаційні технології $i$ засоби навчання, №1 (39), с. $17-45$, 2014. [Електронний ресурс]. Доступно: http://journal.iitta.gov.ua/index.php/itlt/article/view/960/724. Дата звернення: Травень. 20, 2017. 
[8] Т. Вакалюк, “Можливості використання хмарних технологій в освіті”, Міжнар. наук.-практ. конф. Актуальні питання сучасної педагогіки, Острог, 2013, с. 97-99.

[9] А. Бочевар, “Стан сформованості інформаційно-комунікативної компетентності майбутніх юристів” Наука $і$ освіта. Науковий вісник Південноукраӥнського національного педагогічного університету ім. К.Д. Уиинського. Вип.1. 2016. с. 5-10.

[10] Я. Кічук, “Правова компетенція - інваріантна суб'єктна характеристика сучасної студентської молоді” Педагогічна наука: історія, теорія, практика, тендениї розвитку. №3, 2010. [Електронний ресурс]. Доступно: http://www.intellectinvest.org..ua/ukr/pedagog_editions_emagazine_pedagogical_science_vypuski_n3_2010_st_13. Дата звернення: Травень. 21, 2017.

[11] І. Романова, “Компетентнісний підхід до правової освіти студентів” Педагогіка та психологія І. Прокопенко, В. Лозова, Ред. Харків, Курсор. Вип.33. 2008. с. 26-35.

[12] Т. Ремех, "Методичні засади навчання првознавства в процесі допрофільної підготовки школярів”, дис. канд. пед. наук., Інститут педагогіки НАПН України. Київ, 2011.

[13] О. Воронкін, “Тенденції розвитку інформаційно-комунікаційних технологій навчання студентів вищих навчальних закладів України (друга половина XX - початок XXI століття)”, дис. канд. наук., Старобільськ. Д3 „Луганський національний університет імені Т. Шевченка”, Старобільськ, 2016.

[14] С. Литвинова “Формування інформаційно-комунікаційної компетентності (ікк) вчителівпредметників”, Інформаційні технології $і$ засоби навчання, №5 (1), 2008. [Електронний ресурс]. Доступно: http://journal.iitta.gov.ua/index.php/itlt/article/view/143/129. Дата звернення: Травень. 26, 2017.

[15] Кабінет Міністрів України (2011, лист. 23.) Постанова №1392, про Державний стандарт базової i повної загальної середньої освіти. Офіційний вісник України, №11, 2012.

[16] О. Овчарук та ін., Стратегія реформування освіти в Украӥні: Рекомендації з освітньої політики. Київ, Україна: К.І.С., 2003.

[17] О. Пометун, “Компетентнісний підхід у сучасній історичній освіті”, Історія в школах України. №6, c. 3-12, 2007.

[18] О. Овчарук та ін., Компетентнісний підхід у сучасній освіті: світовий досвід та украӥнські перспективи: Бібліотека з освітньої політики. Київ, Україна: К.І.С., 2004.

[19] В. Моштук, “Фахова компетентність як основа проектно-технологічної культури майбутнього вчителя трудового навчання”, Молодь і ринок, №7 (78), с.108-112, 2011.

[20] В. Луговий, “Компетентності та компетенції: поняттєво-термінологічний дискурс", Вищза освіта [Тематичний випуск: Педагогіка вищої школи: методологія, теорія і технології]. №3, дод.1, с.8-14, 2009.

[21] Я. Кічук, “Деякі тенденції розвитку правової компетентності майбутнього соціального педагога в умовах сучасної університетської освіти” [Електронний ресурс]. Доступно: http://www.elid.zakdu.edu.ua/index2.php, Дата звернення: Травень. 28, 2017.

[22] Правова наука. Електронна база даних НАПрН України. “Головна сторінка. Правила користування БД “Правова наука”” [Електронний ресурс]. Доступно: http://db.ippi.org.ua/. Дата звернення: Травень. 23, 2017.

[23] С. Буртовий, "Хмарні технології в освіті: Microsoft, Google, IBM”. [Електронний ресурс]. Доступно: http://oin.in.ua/osvitni-hmary-microsoft-google-ibm-suchasni-instrumenty-formuvannyaosvitnoho-seredovyscha-navchalno-doslidnytskoji-diyalnosti-ditej/. Дата звернення: Травень. 20, 2017.

[24] С. Клепко, “Компетенізація освіти”: обмеження і перспективи”, Постметодика. №1, с. 9-17. 2005.

Матеріал надійшов до редакиї 08.06.2017 p.

\title{
ИСПОЛЬЗОВАНИЕ ИНФОРМАЦИОННО-КОММУНИКАЦИОННЫХ ТЕХНОЛОГИЙ КАК СРЕДСТВА ФОРМИРОВАНИЯ ПРОФЕССИОНАЛЬНОЙ КОМПЕТЕНТНОСТИ БУДУЩИХ МЕНЕДЖЕРОВ И ЭКОНОМИСТОВ В ПРОЦЕССЕ ОБУЧЕНИЯ ПРАВОВЕДЕНИЯ
}

\author{
Ещенко Марина Георгиевна \\ ассистент \\ Донбасская национальная академия строительства и архитектуры, г. Краматорск, Украина \\ ORCID ID 0000-0001-7467-7899 \\ marinsv@ukr.net
}




\begin{abstract}
Аннотация. В статье рассмотрена проблема формирования профессиональной компетентности студентов высших учебных заведений при преподавании курса правоведения. Путем изучения и анализа научно-методической литературы определено понятие компетентность, профессиональная компетентность. Для формирования профессиональной компетентности автор предлагает задачи, для решения которых необходимо использовать информационно-коммуникационные технологии. Отмечено, что предложенные способы предоставляют дополнительные возможности для формирования профессиональной компетентности, способствуют совершенствованию информационной грамотности студентов высших учебных заведений и реализации их правовых возможностей. Актуальность статьи обусловлена необходимостью формирования профессиональной компетентности студентов высших учебных заведений с помощью использования информационно-коммуникационных технологий при преподавании курса правоведения. Было проведено эксперимент на базе Донбасской национальной академии строительства и архитектуры.
\end{abstract}

Ключевые слова: информационно-коммуникационные технологии; будущие специалисты; профессиональная компетентность студентов; облачные технологии.

\title{
USING INFORMATION AND COMMUNICATION TECHNOLOGIES AS A MEANS OF FORMING PROFESSIONAL COMPETENCE OF FUTURE MANAGERS AND ECONOMISTS WHILE TEACHING THE COURSE OF SCIENCE OF LAW
}

\author{
Maryna H. Yeshchenko \\ Assistant Lecturer of the Chair of Economics and Management \\ Donbas National Academy of Building and Architecture, Kramatorsk, Ukraine \\ ORCID ID 0000-0001-7467-7899 \\ marinsv@ukr.net
}

\begin{abstract}
The article presents the problem of forming professional competence of the students of higher educational institutions while teaching science of law. By means of studying and analyzing science and methodical literature the concepts "competence" and "professional competence" are defined. To form professional competence the author offers the tasks to solve which it is necessary to use information and communication technologies. It is noted that the offered means give additional opportunities to form professional competence, contribute to improving information literacy of the students of higher educational institutions and realizing their legal possibilities. The relevance of the article is determined by the necessity of forming professional competence of the students of higher educational institutions by means of using information and communication technologies while teaching the course of science of law. An experiment was conducted on the basis of the Donbas National Academy of Building and Architecture.
\end{abstract}

Keywords: information-communication technologies; future professionals; professional competence of students; cloud technologies.

\section{REFERENCES (TRANSLATED AND TRANSLITERATED)}

[1] V. Prymakov, "Development of postgraduate education of primary school teachers in Ukraine (19482012)", Doctor's thesis., Ternopil National Pedagogical University, Ternopil 2016. (in Ukrainian).

[2] The President of Ukraine (2013, Jun. 25) Ukaz №344/2013. On the national strategy of the development of education in Ukraine for the period till 2021. [Online]. Available: http://zakon4.rada.gov.ua/laws/show/344/2013/page. (in Ukrainian).

[3] S. Netyosov, "Using information-communication technologies at lesson of science of law", Information Technologies and learning Tools, no. 3 (23), 2011. [Online]. Available: http://journal.iitta.gov.ua/index.php/itlt/article/view/489/417. Accessed on: May 23, 2017. (in Ukrainian).

[4] O. Lokshyna, "Competency approach in education: theoretical foundations and practice of implementation", materialy metodol. seminaru, Ch.1, In-t obdarovanoi dytyny NAPN Ukrainy, Kyiv, 2014. (in Ukrainian). 
[5] H. Bezpala, "Components of professional competence of future teachers", Problemy inzhenernopedahohichnoi osvity, no. 44, pp. 14-18, 2014. (in Ukrainian).

[6] N. Smolyana, "Using TMT in teaching and manufacturing process of vocational school in Ukraine (1960 - 1991 of the $20^{\text {th }}$ century)", Information Technologies and learning Tools, Information Technologies and learning Tools, no. 2 (22), 2011. [Online]. Available: http://journal.iitta.gov.ua/index.php/itlt/article/view/349/391. Accessed on: May 10, 2017. (in Ukrainian).

[7] O. Voronkin, "Development of computer technologies of support of learning of students of higher educational institutions of Ukraine (the second half of the $50 \mathrm{~s}-$ the beginning of the $90 \mathrm{~s}$ of the $20^{\text {th }}$ century)", Information Technologies and learning Tools, no. 1 (39), pp. 17 -45, 2014. [Online]. Available: http://journal.iitta.gov.ua/index.php/itlt/article/view/960/724. Accessed on: May 20, 2017. (in Ukrainian).

[8] T. Vakalyuk, "Possibilities of using cloud technologies in education", Mizhnar. nauk.-prakt. konf., Aktualni pytannya suchasnoyi pedahohiky, Ostroh, 2013 pp. 97 - 99. (in Ukrainian).

[9] A. Bochevar "State of future lawyers' informative and communicative competence maturity" Nauka $i$ osvita. Naukovyy visnyk Pivdennoukrayins'koho natsional'noho pedahohichnoho universytetu im. K.D. Ushyns'koho. Vyp.1. 2016. pp. 5-10. (in Ukrainian).

[10] Ya. Kichuk "Legal competence - invariant subjective characteristic of modern student youth" Pedahohichna nauka: istoriya, teoriya, praktyka, tendentsiyi rozvytku. no. 3, 2010. [Online]. Available: http://www.intellect-

invest.org..ua/ukr/pedagog_editions_emagazine_pedagogical_science_vypuski_n3_2010_st_13]/

Accessed on: October 14, 2017. (in Ukrainian).

[11] I. Romanova "Competent approach to legal training of students" Pedahohika ta psykholohiya I. Prokopenko, V. Lozova, Red. Kharkiv, Kursor. Vyp.33. 2008. pp. 26-35. (in Ukrainian).

[12] T. Remekh, "Methodical principles of education of prviznavstva in the process of pre-school preparation of schoolchildren" dys. kand. ped. nauk., Instytut pedahohiky NAPN Ukrayiny. Kyyiv, 2011. (in Ukrainian).

[13] O. Voronkin, "Tendecies of development of information-communication technologies of learning students of higher educational institutions (the second half of the $20^{\text {th }}$ century - the beginning of the $21^{\text {st }}$ century )". Candidate's thesis. Starobilsk. DZ "Luhanskyy natsionalnyy universytet imeni T. Shevchenka", Starobilsk, 2016. (in Ukrainian).

[14] S. Litvinova, "Forming information-communication competence (ICC) of teachers of school subjects", Information Technologies and learning Tools, no. 5(1), 2008. [Online]. Available: http://journal.iitta.gov.ua/index.php/itlt/article/view/143/129. Accessed on: May 26, 2017. (in Ukrainian).

[15] Kabinet Ministriv Ukrayiny (2011, lyst. 23.) Postanova no. 1392, pro Derzhavnyy standart bazovoyi i povnoyi zahal'noyi seredn'oyi osvity. Ofitsiynyy visnyk Ukrayiny, no. 11, 2012. (in Ukrainian).

[16] O. Ovcharuk et al., Strategy of reforming education in Ukraine: Recommendations on Educational Policy. Kyiv, Ukraina: K.I.C., 2003. (in Ukrainian).

[17] O. Pometun, "Competency approach in modern historic education", Istoriia v shkolakh Ukrainy. no. 6, pp.3-12, 2007. (in Ukrainian).

[18] O. Ovcharuk et al., Competency approach in modern education: world experience and Ukrainian perspectives, Biblioteka z osvitnoi polityky. Kyiv, Ukraina: K.I.C., 2004. (in Ukrainian).

[19] V. Moshtuk, "Professional competence as a basis of project-technological culture of future labor education teacher", Molod i rynok, no. 7 (78), pp.108-112, 2011. (in Ukrainian).

[20] V. Luhovyi, "Competences and competencies: Conceptual-terminological discourse”, Vyshcha osvita [Tematychnyi vypusk: Pedahohika vyshchoi shkoly: metodolohiia, teoriia i tekhnolohii]. no. 3, dod 1, pp.8-14, 2009. (in Ukrainian).

[21] Ya. Kichuk, "Some tendencies of development of legal competence of the future social pedagogue in the conditions of modern university education" [Online]. Available: http://www.elid.zakdu.edu.ua/index2.php, Accessed on: October 14, 2017. (in Ukrainian).

[22] Pravova nauka. Elektronna baza danykh NAPrN Ukrayiny. "Holovna storinka. Rules of usage of BD "Science of Law"”. [Online]. Available: http://db.ippi.org.ua/. Accessed on: May 23, 2017. (in Ukrainian).

[23] S. Burtoviy, "Cloud technologies in education: Microsoft, Google, IBM". [Online]. Available: ttp://oin.in.ua/osvitni-hmary-microsoft-google-ibm-suchasni-instrumenty-formuvannya-osvitnohoseredovyscha-navchalno-doslidnytskoji-diyalnosti-ditej/. Accessed on: May 20, 2017. (in Ukrainian).

[24] S. Klepko, "Competencizing of education. Limits and prospects", Postmetodyka. no. 1, pp. 9-17. 2005. (in Ukrainian).

\section{$(\mathrm{cc})$ BY-NC-SA}

This work is licensed under Creative Commons Attribution-NonCommercial-ShareAlike 4.0 International License. 